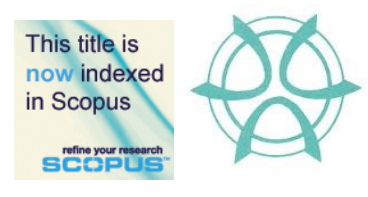

PLANNING MALAYSIA:

Journal of the Malaysian Institute of Planners

VOLUME 17 ISSUE 2 (2019), Page 290 - 301

\title{
MEASURING ATTRIBUTES AND BEHAVIOURAL PATTERNS OF STREET LIVELINESS IN URBAN AREA
}

\author{
Normah Sulaiman $^{1}$, Yusfida Ayu Abdullah $^{2}$ \& Raja Norashekin Raja Othman ${ }^{3}$ \\ ${ }^{1}$ Faculty of Built Environment, Engineering, Technology \& Design \\ TAYLORS' UNIVERSITY \\ ${ }^{2,3}$ Faculty of Architecture, Planning and Surveying \\ UNIVERSITI TEKNOLOGI MARA
}

\begin{abstract}
Streets are essential elements of the form and function of the urban environment. A growing body of research has pointed out that the more human activities in the street, the more interesting the city will be. Streets showcase the community and connect people. They are the most comfortable social environments that provide aesthetical and interactional pleasure for everyone. This paper presents the outcomes of a study which measured street liveliness based on the attributes and behaviours of the pedestrians. The aim of this study was to examine how people experience the liveliness at various times for various activities on the street. To achieve this, the study applied a case study method by looking at one of the streets that showed a diversity of activities with a unique shopping experience and liveliness in Kuala Lumpur called Jalan Masjid India. The method involved two types of data collection techniques, which were site observations, and pedestrian counts. Results which consisted of behavioural mapping and activity analysis revealed that Jalan Masjid India has its own merits in terms of street liveliness, function, and urban activities.
\end{abstract}

Keywords: street, behavioural pattern, street liveliness, urban area 
PLANNING MALAYSIA

Journal of the Malaysia Institute of Planners (2019)

\section{INTRODUCTION}

In the field of urban design, various definitions of public space can easily be found. From good practices around the world, UN-Habitat (2016, p.1) gives the definition of public space as "all places publicly owned or of public use, accessible and enjoyable by all for free and without a profit motive." Each public space has its own spatial, historic, environmental, and economic features. When it comes to the street as a public space, Jacobs' (2011) theory explains that the street is an interesting space. Besides being the vital organ of the city, the tangible facilities between the streets and their sidewalks framed by the buildings permit the streets to become a vibrant place. Koohsari et al. (2015) stated that open spaces influence physical activity in three ways. First is the setting where people engage in physical activity. Next, the public space is a destination for people to socialise, and finally, it can be a route to pass through and reach another destination. Hence, as a thoroughfare, the physical activities are related to active travel, such as transiting, cycling, walking, and running. In short, these three settings contribute to different types of physical activity behaviours.

The aim of this study is to evaluate how people experience the liveliness of the street at various times for various activities. The intention of this study was to understand public street life, and to provide recommendations that could shape public space liveliness. Observational data was used to gain the behavioural patterns on the street and appreciate its physical aspects. Pedestrian counts were conducted to understand the urban activities and public life of the street. The findings focused on strengthening the method applied to promote improvements in evaluating the street as a successful public space.

\section{Streets as Fundamental Shared Spaces}

In an urban environment, the elements that complete its form and function are the streets. Streets are defined as linear three-dimensional spaces enclosed on opposite sides by buildings. Back in the old days, the role of the street was seen as a major thoroughfare for vehicular traffic, while the urban fabric was usually dense, and buildings were built next to one another, and flushed with streets (Sulaiman, Ayu Abdullah, \& Hamdan, 2017). In between these connected masses, the facades of the buildings created the wall of open spaces, finely forming a mesh of street grid on a small scale that defines streets and squares. Roads, streets, boulevards, and avenues act as channels of efficient movement, and as visual elements. Besides their primary purpose, streets also connect people. As interesting as they can be, streets are not only physically a space and a channel of movement, but also a place. They are the most fundamental shared public spaces, and the most vital organs of the city. In contrast, their dullness will reflect the city itself (Jacobs, 2011).

While their role from various perspectives is understood, as a place, streets also reveal the community, and connect people. These connected masses 
Normah Sulaiman, Yusfida Ayu Abdullah \& Raja Norashekin Raja Othman

Measuring Attributes and Behavioural Patterns of Street Liveliness in Urban Area

of buildings create frontages, medians, and streetscapes not only as a route for traffic, but also as a space for connectivity and activities. While they are still accessible by cars, pedestrians are dominant in these most comfortable of social environments, where one can analyse the form and qualities to find their value. Sulaiman et al. (2017) wrote that, through the concept of shared spaces, integrating the needs and demands of different forms of movement adds tremendous value to the streets as the activities are not only for drivers, but are now also safe for cyclists, transit vehicles and users as well as pedestrians of all ages and abilities.

\section{Connecting People and Places}

Traditionally, the street is used as major access for transporting movements. Sholihah and Heath (2016) highlighted that the movement can be walking, riding horses, camels and other animals, using animals to pull carts, cycling, and driving cars and motorcycles etc. As a link from one point to another, the form of movement is purely for circulation. Now that the role of the street as a place is understood, the experience on the street will determine the success of it.

By auditing the transportation nodes, accessibility points, and traffic lanes, the street typology can be ascertained. These tangible qualities help to formulate data on its movement patterns as well as physical and visual linkages and identify the existing functions and activities within it. Commonly, the access and linkage qualities are evaluated by the connections of one area to the surrounding, visually and physically. Carmona, Tiesdell and Oc (2010) pointed out that the sense of movement is visually dynamic, and it provides the opportunity for social interaction and cultural exchange. The wayfinding within the area is relatively good when a user finds it easy to get to and from a place, and when it is also visible both from a distance and up close. Conveniently, it should also be very well connected to public transit to get to adjacent buildings, with good signage so that it leads people to the place easily.

As a shared place, the number of activities in the street becomes great when users have more chances to take part in them although that also depends on the street. When people will find more reasons to come or return to a place as well as have something to do in it, the better the place will be.

\section{METHODOLOGY}

This study employed a case study method as it required a close study of pedestrians on a street. Masjid India Street, or widely known as Jalan Masjid India, was chosen as the case study because of its character as a downtown or market street. Also, the length of the street is suitable to conduct the study while the place itself is vibrant for commerce and able to handle a high volume of pedestrians and high levels of activities throughout the day. In a formal design treatment, downtown streets with high levels of pedestrian activities, distinctive 
visibility, generous sidewalks, and good amenities for the users should be selected.

To analyse the movement of Jalan Masjid India, the researchers used direct observations, and the counting approach as tools to measure its attributes and behavioural patterns. Mehta (2014) stated that an effective method to understand the selected location where people gather for activities to engage in is by mapping the active and passive activities of those people. On the other hand, in studies on understanding public life, counting is the cheapest method to do so, and can give the numbers for comparisons of attributes between different geographic areas, or over time (Gehl \& Svarre, 2018).

To be able to use both methods, the survey points were carefully selected to capture the needs of the research in registering the number of people who were moving or stationary at the spot. The sample size selected was 18 pedestrians using systematic random sampling, which was based on a similar study carried out by Fauzi and Aditianata (2018). To calculate the pedestrian movement per hour, the count was conducted for precisely ten minutes, and repeated. The sample size was set to be easy for observation, and calculation intervals were selected in such a way to avoid fatigue for the observer as the process required a great amount of focus. Times of observation were divided into three periods: morning (08:00-10:00), afternoon (12:00-14:00), and evening (16:00-18:00), and the ideal number of pedestrians passing a point ranged from 8 to 18 pedestrians per minute per metre.

Nodes or observation points were determined by identifying the active points in front of opened and closed facades along the street. To conduct the observations, Jalan Masjid India was divided into three (3) block sections to ease the process. Each block section was 100 metres, a considerable yet walkable distance, and the total blocks in the study area were within 300 metres. Figure 1 below demonstrates the flow of tasks in conducting the study.

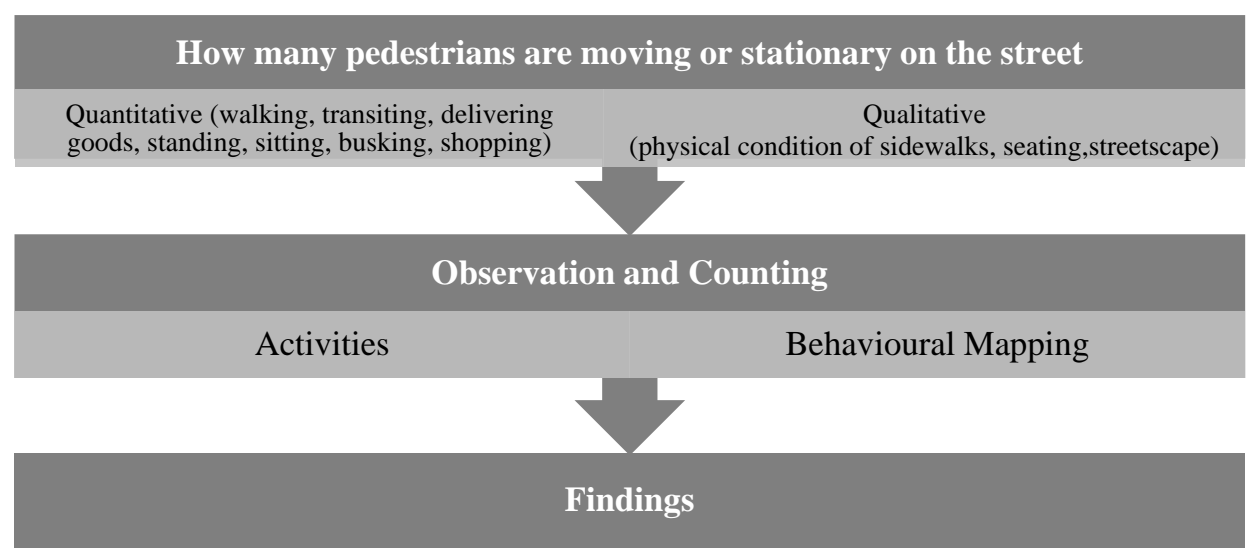

Figure 1: Study approach 
Normah Sulaiman, Yusfida Ayu Abdullah \& Raja Norashekin Raja Othman

Measuring Attributes and Behavioural Patterns of Street Liveliness in Urban Area

\section{Jalan Masjid India - The Case Study}

Jalan Masjid India is in the old heritage zone in the vicinity of Masjid Jamek, which has a strong sense of character amidst heritage buildings, contemporary architecture, and preserved facades. This area is famously known for the community's commercial activities, and as a trading area. The vibrancy of Jalan Masjid India is not the only reason for it being the most popular tourist attraction, but here, one can also find the mosque that holds 150 years of history. The activities make the street lively and active. At every festive month, especially during the month of Ramadhan for Muslim believers, and Deepavali for the Hindu believers, this street is the main destination for people to come and shop for their festive preparations, simply because of its vibe and sense of place. Daily, the public finds that this street serves as a vital transit, and observes a significant number of people on foot, whilst various activities from commercial to leisure purposes take place along this street. Figure 2 demonstrates the location of Jalan Masjid India in Kuala Lumpur surrounded by several landmarks, while Figure 3 shows the 300-metre stretch of the street determined for the study.

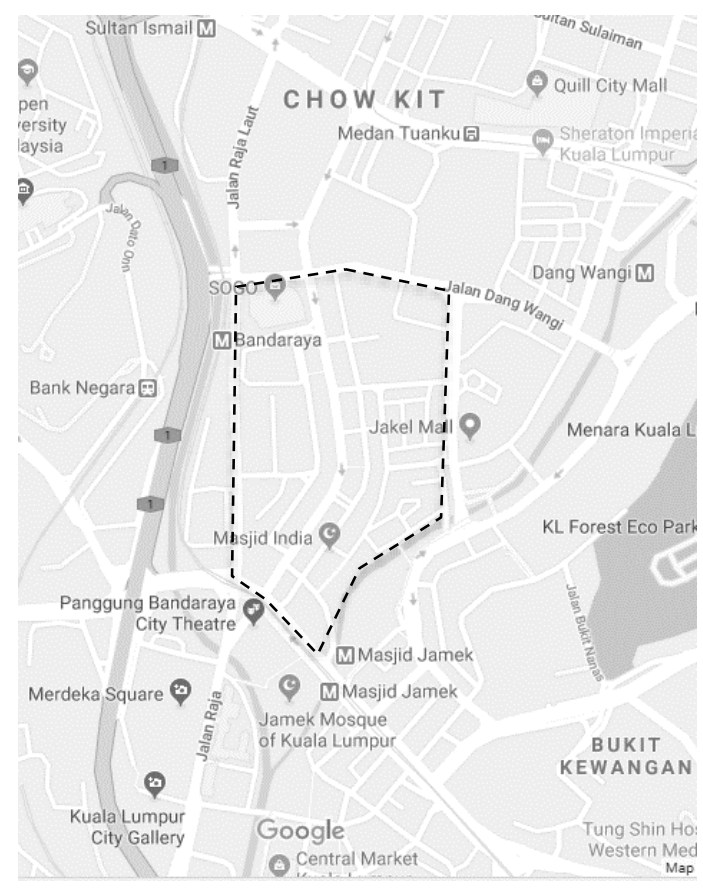

Figure 2 Key plan of Jalan Masjid India Source: Google Maps (2018a) 


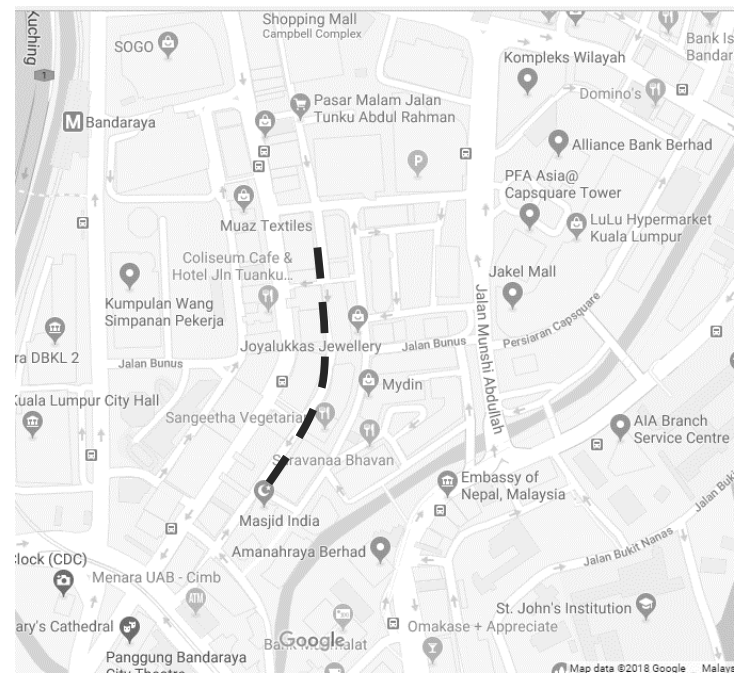

Figure 3 Section of Jalan Masjid India as the case study stretching about 300m Source: Google Maps (2018b)

\section{RESULTS AND DISCUSSION}

In most Malaysian towns, streets play an important role as settings for activities. With the tropical weather, activities are drawn outdoors, and are more active in the evening (Heng, Low \& Hee, 2010). The physical character of a street is also very much influenced by the activities taking place in it as well as within the buildings flanking it. For each of the three selected sections of Jalan Masjid India, the results of the findings were summarised in a table and a behavioural mapping of the dynamic (active) and static (passive) activities.

Based on the results, the flow of movement on Section 1 shown in Figure 4 gradually increased to a more dynamic situation from morning to afternoon. Active activities like walking and transiting were very significant in the afternoon, and a balance of static activities also took place in the afternoon. The streets were very lively in the afternoon, where users of the area were seen as comfortable, with them chatting and waiting on the street, sitting by the sidewalks and resting, and people-watching under a tree, all of which are summarised in Table 1. A lot of the activities took place on the street itself regardless of the weather condition. From the observations, the physical condition of the street and the sidewalks were good to foster both the active and passive activities that took place during that time. As the street was busy with its trading activities, the researchers discovered that the workers and traders were transporting goods during peak hours until evening. This is shown in Figure 4 and Table 1. 
Normah Sulaiman, Yusfida Ayu Abdullah \& Raja Norashekin Raja Othman

Measuring Attributes and Behavioural Patterns of Street Liveliness in Urban Area

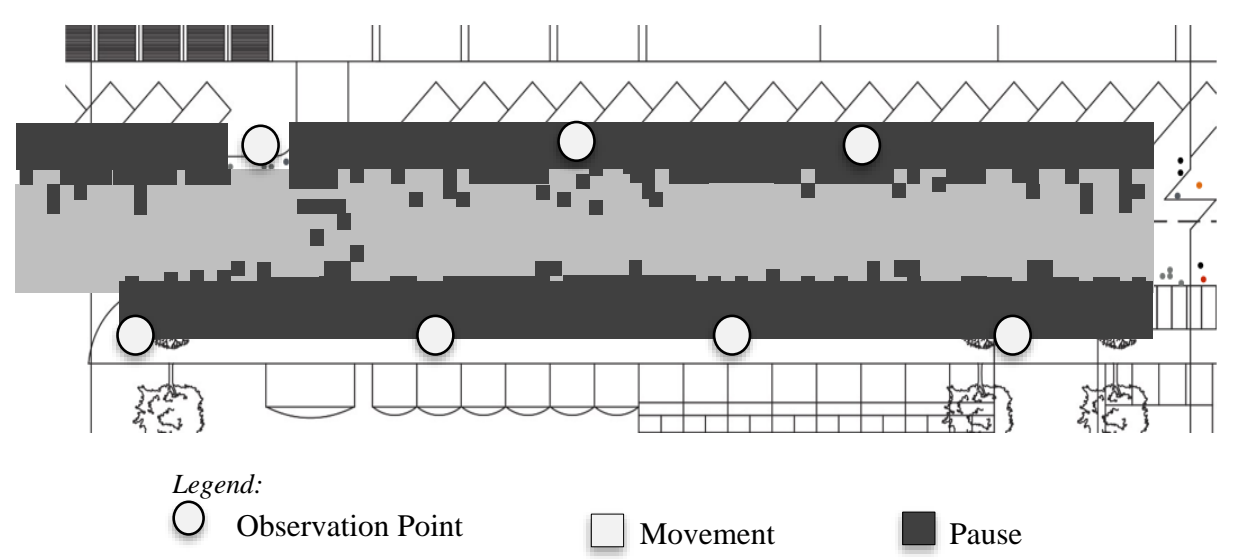

Figure 4: Movement and pause points on Section 1 of Jalan Masjid India (Length: $100 \mathrm{~m})$

Table 1 Summary of number of pedestrians passing by observation points and engaging in dynamic and static activities for more than 3 minutes on Section 1 of Jalan Masjid India throughout the day (Length: $100 \mathrm{~m}$ )

\begin{tabular}{|c|c|c|c|c|c|c|c|c|c|c|}
\hline & \multirow[t]{2}{*}{ Activities } & \multicolumn{3}{|c|}{ Morning } & \multicolumn{3}{|c|}{ Afternoon } & \multicolumn{3}{|c|}{ Evening } \\
\hline \multirow{4}{*}{ } & & & ه̆ & $\begin{array}{l}\stackrel{0}{\ddot{\theta}} \\
\end{array}$ & 氙 & 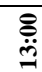 & $\begin{array}{l}\stackrel{8}{\ddot{U}} \\
\end{array}$ & 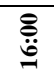 & 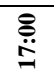 & $\begin{array}{l}\mathscr{\ddot { d }} \\
\ddot{\theta}\end{array}$ \\
\hline & Walking & 7 & 8 & 7 & 4 & 15 & 17 & 12 & 15 & 12 \\
\hline & $\begin{array}{lll}\text { Passing } & \text { By } \quad / \\
\text { Transiting } & \end{array}$ & 7 & 9 & 12 & 5 & 18 & 18 & 16 & 17 & 15 \\
\hline & Transporting Goods & 1 & 0 & 3 & 0 & 4 & 3 & 2 & 3 & 2 \\
\hline \multirow{7}{*}{ } & Sitting & 2 & 1 & 3 & 2 & 6 & 10 & 3 & 4 & 7 \\
\hline & Waiting & 4 & 2 & 5 & 2 & 8 & 7 & 6 & 5 & 8 \\
\hline & People-Watching & 1 & 0 & 2 & 1 & 5 & 8 & 5 & 4 & 3 \\
\hline & Chatting & 2 & 3 & 4 & $\overline{4}$ & 5 & 12 & 7 & 9 & 12 \\
\hline & Window Shopping & 0 & 0 & 0 & 0 & 3 & 6 & 5 & 8 & 9 \\
\hline & Busking & 0 & 0 & 0 & 0 & 0 & 3 & 0 & 2 & 0 \\
\hline & Shopping & 1 & 5 & 8 & 8 & 5 & 16 & 5 & 7 & 7 \\
\hline \multicolumn{2}{|c|}{$\begin{array}{r}\text { Total Activities Engaged } \\
\text { by Pedestrians }\end{array}$} & 25 & 28 & 44 & 26 & 69 & 100 & 66 & 74 & 75 \\
\hline
\end{tabular}

In Section 2 (Figure 5), the study revealed that there was a balance of active and passive activities which took place here. The tree-lined sidewalks attracted more passive activities like sitting, waiting, chatting, and peoplewatching from afternoon to evening. This is because the physical condition of the sidewalk gave a sense of security for the users to just pause within the space. However, the flow of movement did gradually rise in the afternoon. The existing physical condition of the sidewalks could not support the larger volume of 
pedestrians at the crossings in these parts as seen in Figure 5. Some passive activities, and the display of items from the shops had also occupied the space for pedestrians to walk in this section.

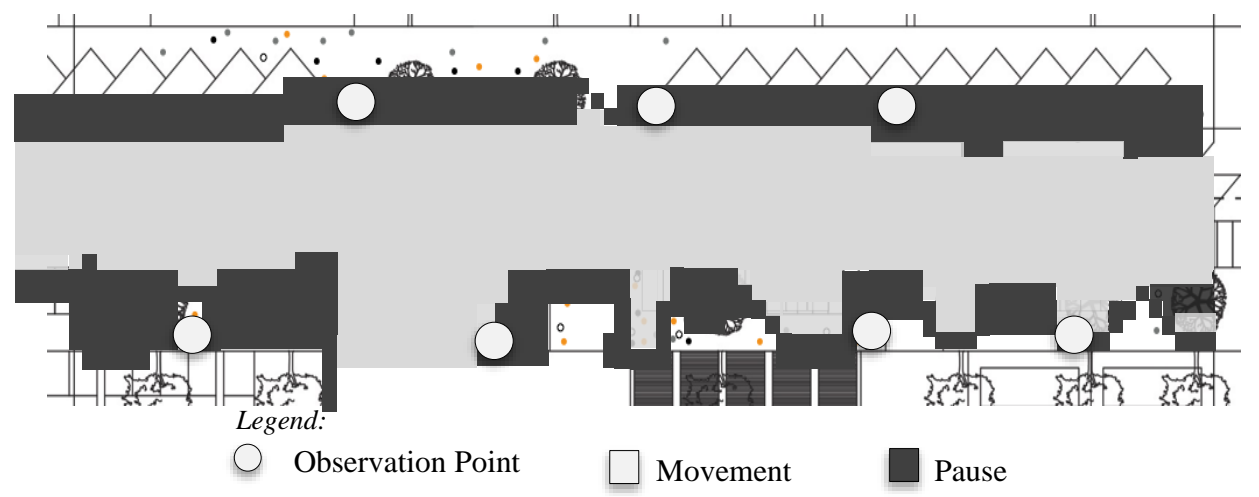

Figure 5 Movement and pause points on Section 2 of Jalan Masjid India (Length: $100 \mathrm{~m})$

Table 2 Summary of number of pedestrians passing by observation points and engaging in dynamic and static activities for more than 3 minutes on Section 2 of Jalan Masjid India throughout the day (Length: 100m)

\begin{tabular}{|c|c|c|c|c|c|c|c|c|c|c|}
\hline & Activities & & rni & & & tern & & & ven & \\
\hline . & & $\overbrace{\ddot{0}}$ & ڤ̆ & 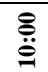 & $\begin{array}{l}\text { تِ } \\
\text { }\end{array}$ & 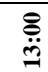 & 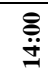 & & & 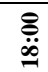 \\
\hline ฮี & Walking & 5 & 8 & 6 & 10 & 15 & 17 & 12 & 15 & 12 \\
\hline క. & Passing By / Transiting & 8 & 9 & 12 & 8 & 18 & 18 & 16 & 17 & 15 \\
\hline & Transporting Goods & 0 & 0 & 3 & 2 & 4 & 3 & 2 & 3 & 2 \\
\hline & Sitting & 1 & 1 & 3 & 2 & 5 & 7 & 7 & 10 & 10 \\
\hline & Waiting & 2 & 2 & 5 & 2 & 8 & 7 & 10 & 9 & 12 \\
\hline & People-Watching & 2 & 1 & 0 & 1 & 5 & 4 & 5 & 4 & 3 \\
\hline 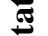 & Chatting & 2 & 3 & 4 & 4 & 8 & 12 & 7 & 9 & 12 \\
\hline & Window Shopping & 0 & 0 & 0 & 0 & 3 & 6 & 5 & 8 & 9 \\
\hline & Busking & 0 & 0 & 0 & 0 & 0 & 3 & 0 & 2 & 0 \\
\hline & Shopping & 0 & 4 & 2 & 8 & 8 & 16 & 10 & 15 & 7 \\
\hline & $\begin{array}{r}\text { tal Activities Engaged } \\
\text { by Pedestrians }\end{array}$ & 20 & 28 & 35 & 37 & 87 & 90 & 79 & 92 & 82 \\
\hline
\end{tabular}

Table 2 above demonstrates the movement overflowed onto the street level itself. Pedestrians created their own imaginary lane to comfortably shop, walk, transit, and transport goods next to moving vehicles along the street. At the main intersection, conflict between pedestrians and vehicles occurred, slowing down the movement of vehicles in the area. Nevertheless, the liveliness, movement, and pause of movements in these parts of Jalan Masjid 
Normah Sulaiman, Yusfida Ayu Abdullah \& Raja Norashekin Raja Othman

Measuring Attributes and Behavioural Patterns of Street Liveliness in Urban Area

India continued throughout the day as the main intersection of the road allowed users to move from one place to the adjacent.

It was also discovered that Section 3 of Jalan Masjid India (Figure 6) showed that the movement here was more dynamic from late afternoon to evening. This area had a different network of users and needs. The sidewalks seemed calmer than other sections of the street, and were not filled with any obstructions, pop-up hawkers, or buskers. Noticeably, static activities took place around natural attractions nearby curbs and streets, and the physical condition of the sidewalks was comfortable to foster both dynamic and static activities. This is presented in Table 3 . The streets also connected users to a nearby intersection that was important considering the potential flows and volumes of movements of all user groups heading to Jalan Masjid India. However, pedestrian conflicts were visible in the evening especially with vehicles exiting parking areas from a nearby building and by-passing secondary roads to the main road.

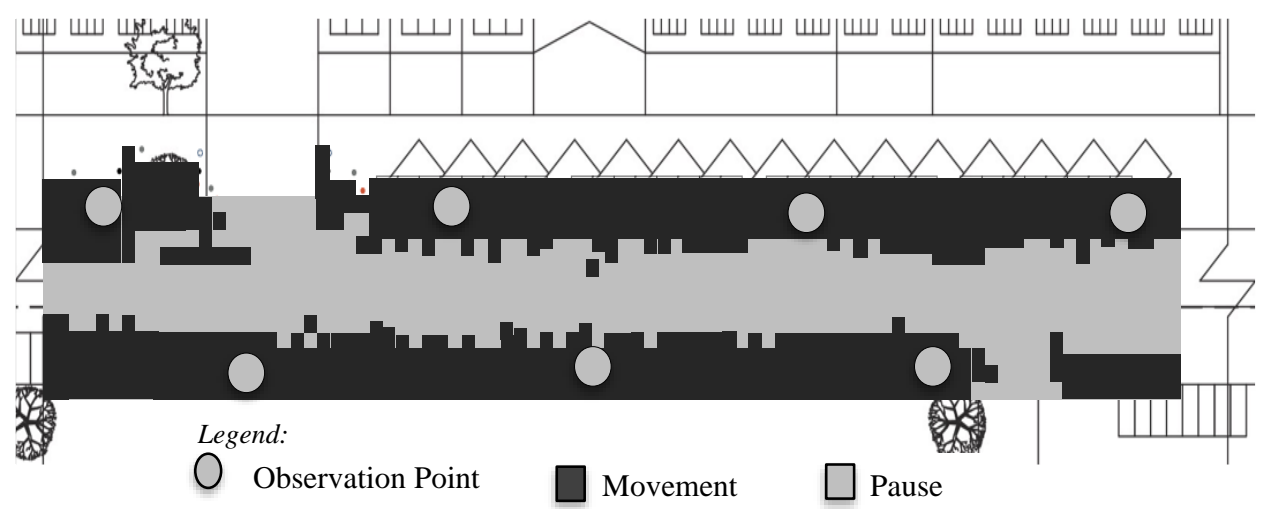

Figure 6 Movement and pause points on Section 3 of Jalan Masjid India (Length:

$100 \mathrm{~m})$

Table 3 Summary of number of pedestrians passing by observation points and engaging in dynamic and static activities for more than 3 minutes on Section 3 of Jalan Masjid India (Length: $100 \mathrm{~m})$

\begin{tabular}{|c|c|c|c|c|c|c|c|c|c|c|}
\hline & \multirow[t]{2}{*}{ Activities } & \multicolumn{3}{|c|}{ Morning } & \multicolumn{3}{|c|}{ Afternoon } & \multicolumn{3}{|c|}{ Evening } \\
\hline \multirow{4}{*}{ 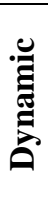 } & & $\ddot{\ddot{\infty} 0}$ & $\ddot{\ddot{\theta} \theta}$ & $\ddot{\Xi} 8$ & $\ddot{\ddot{z}} 8$ & $\ddot{3} 8$ & $\ddot{ \pm} 8$ & $\ddot{\Xi} 8$ & $\ddot{\Xi} 8$ & $\ddot{\otimes} 8$ \\
\hline & Walking & 3 & 8 & 3 & 3 & 10 & 11 & 12 & 15 & 12 \\
\hline & $\begin{array}{l}\text { Passing By } \\
\text { Transiting / }\end{array}$ & 4 & 5 & 5 & 5 & 15 & 8 & 16 & 17 & 15 \\
\hline & Transporting Goods & 2 & 2 & 4 & 3 & 4 & 3 & 2 & 3 & 2 \\
\hline \multirow{4}{*}{ 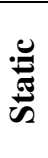 } & Sitting & 2 & 1 & 3 & 2 & 6 & 10 & 3 & 4 & 7 \\
\hline & Waiting & 4 & 2 & 5 & 2 & 8 & 7 & 6 & 5 & 8 \\
\hline & People-Watching & 1 & 0 & 2 & 1 & 5 & 8 & 5 & 4 & 3 \\
\hline & Chatting & 2 & 3 & 4 & 4 & 5 & 12 & 7 & 9 & 12 \\
\hline
\end{tabular}


PLANNING MALAYSIA

Journal of the Malaysia Institute of Planners (2019)

\begin{tabular}{lrrrrrrrrr}
\hline Window Shopping & 0 & 0 & 0 & 0 & 3 & 6 & 5 & 8 & 9 \\
\hline Busking & 0 & 0 & 0 & 0 & 0 & 3 & 0 & 2 & 0 \\
\hline Shopping & 1 & 2 & 3 & 3 & 5 & 10 & 5 & 5 & 5 \\
\hline $\begin{array}{c}\text { Total Activities Engaged } \\
\text { by Pedestrians }\end{array}$ & 19 & 24 & 29 & 23 & 61 & 78 & 61 & 65 & 74 \\
\hline
\end{tabular}

\section{Movement along Jalan Masjid India}

The movement along Jalan Masjid India was represented by the public, which included people of all abilities and ages sitting, walking, pausing, and resting on the streets. The study area was evaluated and found to be well connected and easy to access. However, on some days, especially weekends, and during peak hours on weekdays, conflicts between pedestrians and vehicles seemed visible due to the activities that were simultaneously taking place.

The physical condition of the Jalan Masjid India sidewalks was found to be satisfactory for walking. The continuous design spaces were adequate to link users to and from adjacent places. The evaluation indicated that the sidewalks were wide and comfortable enough to accommodate high numbers of users with minimal clashes as summarised in Tables 1, 2, and 3 above. The major pause points in the movement, as shown in Figures 4, 5, and 6 earlier, were mainly the vendors, street stall operators, and owners of commercial storefronts. Adequate spaces were allocated to these users that support the vibrant, active, and engaging street environment.

The overall movement and pause points of Jalan Masjid India were good for a street environment, where the buildings create frontages, and its streetscape showcases the people using the space for connectivity and activities. However, to improve the quality of the street, regular cleaning and maintenance is required to support the commercial activities along the street. Besides that, protection from extreme weather should also be incorporated to ensure an enjoyable street experience for the users.

\section{CONCLUSION}

The findings of the study revealed that the movement and activities along Jalan Masjid India were very lively with a significant number of people on foot noted throughout the observation exercise. These people brought life to the street throughout the day even though there were conflicts between pedestrians and vehicles which were visible at certain times. Despite the extreme transitions between rainy and hot days, the results proved that users were still comfortable walking to adjacent places. Thus, clearly, Jalan Masjid India is functional, and its physical character acts as a comfortable mode of movement for users.

The potential of the street as a great public space is seen as possible if the street design and soft landscape were more defined and focused. The study concludes that the walkability of the street is good although there were some challenges, such as poorly maintained footways, and broken pavements. The 
Normah Sulaiman, Yusfida Ayu Abdullah \& Raja Norashekin Raja Othman

Measuring Attributes and Behavioural Patterns of Street Liveliness in Urban Area

research also identified the active and passive areas that can foster engagement of interactions, and that an urban designer must avoid the creation of empty spaces that are not well-connected to the pedestrian network on a larger scale.

Ultimately, from the study, it can be determined that some changes can be made to the street as it seems flexible enough to adapt without affecting current core businesses of the street through a flexible street management approach. Through this tactic, the character of Jalan Masjid India as a downtown market street was highlighted using design treatments while still allowing it to handle a high volume of pedestrians and activities. The planning of the design treatments should also consider the street context and limits as well as potential flows and volumes of movement of all user groups coming from nearby streets into Jalan Masjid India. Gradually, this will give time for users to adapt to the changes, and the street's liveliness, function, and urban activities. Henceforth, the street will be able to function to full capacity, where people can enjoy many social and outdoor activities.

\section{ACKNOWLEDGEMENTS}

The authors would like to thank Taylor's University and Universiti Teknologi MARA (UiTM) for supporting the research.

\section{REFERENCES}

Carmona, M. Tiesdell, S., \& Oc, T. (2010). Public places, urban spaces. Oxford, UK: Architectural Press.

Gehl, J., \& Svarre, B. (2018). How to study public life. Washington: Island Press.

Fauzi, A., \& Aditianata, A. (2018). Spatial Analysis in determining physical factors of pedestrian space livability, Case study: Pedestrian space on Jalan Kemasan, Yogyakarta. IOP Conference Series: Earth and Environmental Science, 123, 012042.

Google Maps (2018a). Jalan Masjid India. Retrieved from https://www.google.com/maps/ @3.1542198,101.6962938,16.25z

Google Maps (2018b). Jalan Masjid India. Retrieved from https://www.google.com/maps/ @3.1535906,101.696556,16.75z

Heng, C. K,, Low, B. L. \& Hee, L. (2010). On Asian streets and public space. Singapore: NUS Press.

Jacobs, J. (2011). The death and life of great American Cities (1st ed). New York: Modern Library.

Koohsari, M., Mavoa, S., Villanueva, K., Sugiyama, T., Badland, H., ...\& Giles-Corti, B. (2015). Public open space, physical activity, urban design and public health: Concepts, methods and research agenda. Health \& Place, 33, 75-82.

Mehta, V. (2014) The street. London: Routledge Taylor \& Francis Group

Sholihah, A.B. \& Heath, T. (2016) Assessing the quality of a traditional street in Indonesia: The diversity indicator. In AMER Intnternational Conference of Quality of Life, February 25-27, 2016, Medan, Indonesia. 
PLANNING MALAYSIA

Journal of the Malaysia Institute of Planners (2019)

Sulaiman, N., Ayu Abdullah, Y., \& Hamdan, H. (2017). Street as public space Measuring street life of Kuala Lumpur. IOP Conference Series: Materials Science And Engineering, 245, 082025.

UN-Habitat. (2016). Charter of public space. Instituto Nazionale di Urbanistica.

Received: $12^{\text {th }}$ January 2019. Accepted: $2^{\text {nd }}$ August 2019 